\title{
Knowledge, Attitude and Practice of Nigerian Preclinical Students to Cadaver Dissection
}

\author{
Emue EwonuBari Bernard ${ }^{1}$, Danladi Sambo Amaza ${ }^{2}$, Aniah Julius Akomaye ${ }^{3}$, \\ Onwih Etim Efiong. \\ 1, 3, 4 Department of Anatomical Sciences, Faculty of Basic Medical Sciences, College of Health Sciences, \\ University of Abuja, PMB 117.FCT, Nigeria. \\ ${ }^{2}$ Department of Human Anatomy, Preclinical, College of Medical Sciences, University of Maiduguri, \\ P.M.B.1069 Maiduguri, Borno State, Nigeria.
}

\begin{abstract}
Studies by sociologists have found that no experience has a more profound impact on medical school students than the first encounter with death, which typically occurs during the first-year course of gross anatomy. This study was conducted to access the emotional state at first and during dissection of preclinical medical students. The survey spans a period of 18 months from May 2009-November, 2010 among 212 preclinical students of 2009 to 2010 academic sessions of Universities of Abuja and Maiduguri. It was a cohort study with data acquired with structured questionnaires analyzed by simple percentage methods. The results showed that there were no formal course/orientations/lectures offered to the students before first dissection. Most students were afraid, jittered, and sympathetic and believed that cadaver carries infection at first dissection. Students amongst others make noise, gossip and carelessly uncover dissected parts/bodies at dissections. Furthermore, most staff did not regularly assist students (at dissections). However, all students respect cadaver and acknowledge it importance in their studies. We conclude that a formal course on KAP of cadaver dissection should be introduced and made compulsory for all first year preclinical students. KAP study of cadaver dissection may differ from center to center and requires further evaluation.
\end{abstract}

Keywords: Knowledge, Attitude, Practice, Preclinical Students, cadaver dissection, Nigerian

\section{Introduction}

Knowledge, attitude and practice (KAP) studies are highly focused evaluations that measure changes in human knowledge, attitudes and practices in response to a specific intervention, usually outreach, demonstration or education [1]. In human anatomy, dissection could be regarded as the procedure of exposing structures in such a way that their locations, shapes, sizes, thickness, consistency and distribution can be determined [2]. Andreas Vesalius (1514-1564) was the first medical student to dissect the cadaver and also continued with it even as a profession [3] and [4]).

Experience over the years has shown that many students had little or no formal knowledge about cadaver dissections before entry into the dissecting room. Even before entering the anatomy laboratory, a student, at some level, knows that the first patient that he/she will care for is a dead one and experience considerable anxiety and stress [4]. Students rapidly develop a coping mechanism which enables them to view cadaver dissection as an occupation quite divorced from living human beings [5]. Students should be advised to prepare mentally and emotionally before entering the dissection room so that they are emotionally involved and stimulated [4] and [6]. The majority of students expressed a negative experience; hence it is necessary to support them before initiation dissection [7].

The proper time, means and methods of communication about cadaver dissection to these students at the early stage of their studies is still a case of arguments and controversy among anatomists. It is pertinent to note that cadaver dissection and its value to anatomy education is a topic of much interest to anatomists and medical students [8]. Therefore, this survey was conducted to assess the KAP of preclinical Nigerian students in relation to cadaver dissection.

\section{Materials And Methods}

This survey was conducted for over a period of 18 months from May 2009-November, 2010 among 212 preclinical (Human Anatomy, Bachelor of Medicine, Bachelor of Surgery, (MBBS) and Bachelor of Dental Surgery, (BDS) 200 and 300 level students of Universities of Abuja and Maiduguri. These students had cadaver dissection as a compulsory course in gross anatomy between 2009 to 2010 academic session. Random sampling technique with open and close-ended questionnaires was adopted. The students who were willing to fill the questionnaire were given explanation on the benefit of the study before being allowed to complete it. Again, peer group discussion on filling the questionnaires were discouraged as the consequences of that were disclosed 
to the students. Equal distribution of the questionnaires to both male and female students was done. Data obtained from the study, were analyzed using simple percentage method.

\section{Results}

212 questionnaires were distributed to respondents, out of which $204(96 \%)$ were analyzed while 8 (4\%) were discarded because of wrong completion. The result is shown in the table below:

Table 1: Use of cadaver, orientation before dissection, assisted at dissection and alternative dissection (N0/\%= Number/percentage).

\begin{tabular}{|c|c|c|c|c|}
\hline Responses & $\begin{array}{l}\text { Use of cadaver } \\
(\mathrm{No} / \%)\end{array}$ & $\begin{array}{l}\text { Formal course/ } \\
\text { Orientation/lecture } \\
\text { before dissection } \\
(\text { No } / \%)\end{array}$ & $\begin{array}{l}\text { Assisted at first } \\
\text { dissection } \\
\left(N_{0} / \%\right)\end{array}$ & $\begin{array}{l}\text { Alternative } \\
\text { to } \\
\text { dissection } \\
\left(\mathrm{No}_{0} / \%\right)\end{array}$ \\
\hline Yes & $204(100)$ & $79(39)$ & $22(11)$ & $37(18)$ \\
\hline No & $\mathrm{Ni1}$ & $125(61)$ & $182(89)$ & $167(82)$ \\
\hline Total & \multicolumn{4}{|c|}{204} \\
\hline
\end{tabular}

Table 1 indicates that $100 \%$ of the medical students use cadaver for dissection. $61 \%$ of the students had no orientation before dissection while 39\% did. $89 \%$ of the students reported that they were not assisted at first dissection while $11 \%$ were assisted. $82 \%$ of the students indicate that there was no alternative to dissection but $18 \%$ agree that there was an alternative.

Table 2 indicates that $60 \%$ of the students were afraid but $40 \%$ were not afraid on seeing cadaver for the first time. 53\% of the students jittered/nervous while $47 \%$ did not. $94 \%$ of the respondents did not collapse but $6 \%$ did. Again, $98 \%$ of the respondents sympathized with cadaver while 5\% did not. $99 \%$ of the respondents disagree that cadaver has a ghost that kills but very few (1\%) agreed it. $88 \%$ of the students believes that cadaver carries infections but few (12\%) did not. Furthermore, $94 \%$ of students did not agree that cadaver ghost can be seen in dreams while 6\% agreed. Most (98\%) of the respondents did not believe that Cadaver ghost appears physically to pursue students in the laboratory but very few (2\%) believed it.

Table 2: Reactions on seeing cadaver for the first time and impression about cadaver dissection (No/\%= Number/percentage)

\begin{tabular}{|c|c|c|c|c|c|c|c|c|}
\hline \multicolumn{5}{|c|}{ Reactions on seeing cadaver for the first time } & \multicolumn{4}{|c|}{ Impressions about cadaver dissection } \\
\hline Response & Afraid & $\begin{array}{l}\text { Jittering/ } \\
\text { Nervous }\end{array}$ & Collapse & $\begin{array}{l}\text { Sympathy } \\
\text { with } \\
\text { cadaver }\end{array}$ & $\begin{array}{l}\text { Cadaver } \\
\text { has a } \\
\text { ghost } \\
\text { that kills }\end{array}$ & $\begin{array}{l}\text { Cadaver } \\
\text { carries } \\
\text { infections }\end{array}$ & $\begin{array}{l}\text { Cadaver } \\
\text { ghost can } \\
\text { be seen in } \\
\text { dreams }\end{array}$ & $\begin{array}{l}\text { Cadaver ghost } \\
\text { appears and } \\
\text { pursue physically } \\
\text { students in the } \\
\text { lab. }\end{array}$ \\
\hline Yes & $123(60)$ & $109(53)$ & $12(6)$ & $199(98)$ & $2(1)$ & $179(88)$ & $13(6)$ & $3(2)$ \\
\hline No & $81(40)$ & $95(47)$ & $192(94)$ & $5(2)$ & $202(99)$ & $25(12)$ & $191(94)$ & $201(98)$ \\
\hline Total & & & & 204 & & & & \\
\hline
\end{tabular}

Table 3: Practices at cadaver dissection (No/\% $=$ Number $/$ percentage)

\begin{tabular}{|c|c|c|c|c|c|c|c|c|c|}
\hline Response & $\begin{array}{l}\text { Respect } \\
\text { for } \\
\text { cadaver } \\
(\text { No } / \%)\end{array}$ & $\begin{array}{l}\text { Playing/ } \\
\text { Dancing } \\
\text { in the } \\
\text { laboratory } \\
(\text { No } / \%)\end{array}$ & $\begin{array}{l}\text { Littering } \\
\text { of } \\
\text { dissected } \\
\text { parts } \\
(\mathrm{No} / \%)\end{array}$ & $\begin{array}{l}\text { exposure } \\
\text { of } \\
\text { undissected } \\
\text { parts } \\
\text { /bodies } \\
(\text { No } / \%)\end{array}$ & $\begin{array}{l}\text { Noise } \\
\text { making/ } \\
\text { Gossiping } \\
\text { at } \\
\text { dissection } \\
(\text { No } / \%) \\
\end{array}$ & $\begin{array}{l}\text { Eating/ } \\
\text { Chewing } \\
\text { gums at } \\
\text { dissection } \\
(\mathrm{No} / \%)\end{array}$ & $\begin{array}{l}\text { Stealing } \\
\text { of } \\
\text { dissected } \\
\text { part } \\
(\text { No } / \%)\end{array}$ & $\begin{array}{l}\text { Unacceptable } \\
\text { public Sexual } \\
\text { behavior } \\
\left(\mathrm{No}_{0} / \%\right)\end{array}$ & $\begin{array}{l}\text { Fighting } \\
(\mathrm{No} / \%)\end{array}$ \\
\hline Yes & $\begin{array}{l}204 \\
(100)\end{array}$ & Nil & $56(28)$ & $113(55)$ & $105(52)$ & $4(2)$ & Ni1 & Nil & Nil \\
\hline No & $\mathrm{Ni1}$ & $204(100)$ & $148(72)$ & $91(45)$ & $99(48)$ & $200(98)$ & $\begin{array}{l}204 \\
(100)\end{array}$ & $\begin{array}{l}204 \\
(100)\end{array}$ & $\begin{array}{l}204 \\
(100)\end{array}$ \\
\hline
\end{tabular}

Table 3 result shows that $100 \%$ of students respect cadaver, did not play or dance in the laboratory, did not steal dissected part (s), did not involve in Unacceptable public Sexual behavior and no fighting at dissection. Again, $72 \%$ of the students did not litter dissected parts but $28 \%$ did so. $55 \%$ of the respondents agreed that after dissection they exposed undissected parts while $45 \%$ covers it. $52 \%$ of the students accepted making noise/gossip at dissection but $48 \%$ did not. 
Knowledge, Attitude And Practice of Nigerian Preclinical Students To Cadaver Dissection

Table 4: Benefit of cadaver dissection and factors that will improve KAP of cadaver dissection

\begin{tabular}{|c|c|c|c|c|c|c|c|c|}
\hline \multicolumn{6}{|c|}{ Benefits of cadaver dissection } & \multicolumn{3}{|c|}{$\begin{array}{l}\text { Factors that may improve KAP of } \\
\text { cadaver dissection }\end{array}$} \\
\hline Responses & $\begin{array}{l}\text { Enhance } \\
\text { understanding } \\
\text { of the course }\end{array}$ & $\begin{array}{l}\text { Provide } \\
\text { true } \\
\text { picture } \\
\text { of } \\
\text { human } \\
\text { structure }\end{array}$ & $\begin{array}{l}\text { Manual } \\
\text { /surgical } \\
\text { skill } \\
\text { learned }\end{array}$ & $\begin{array}{l}\text { Reveals } \\
\text { variations } \\
\text { /anomalies } \\
\text { of } \\
\text { structures }\end{array}$ & $\begin{array}{l}\text { Distinguish } \\
\text { medical } \\
\text { from } \\
\text { nonmedical } \\
\text { students }\end{array}$ & \begin{tabular}{|l|} 
Early \\
formal \\
course/ \\
orientation \\
/lecture \\
before \\
dissection
\end{tabular} & $\begin{array}{l}\text { Staff } \\
\text { assistance } \\
\text { /guidance } \\
\text { at first } \\
\text { dissection }\end{array}$ & $\begin{array}{l}\text { Punishment/ } \\
\text { caution for } \\
\text { wrong } \\
\text { practices at } \\
\text { dissection }\end{array}$ \\
\hline No $/ \%$ & $66(32)$ & $45(22)$ & $34(17)$ & $31(15)$ & $28(14)$ & $177(86)$ & $22(11)$ & $5(3)$ \\
\hline Total & \multicolumn{8}{|c|}{204} \\
\hline
\end{tabular}

$\mathrm{N} 0 / \%=$ Number $/$ percentage. $\mathrm{KAP}=$ Knowledge, Attitude and Practice

Table 4 shows that $32 \%$ of the benefit of dissection was enhancing understanding of the course. Other benefits include: provision of true picture of human structure (22\%), manual/surgical skill learned (17\%), reveals variations/anomalies of structures (15\%) and distinguish medical from nonmedical students (14\%). Early orientation/formal course before dissection (86\%) was the most important factor to improve KAP of cadaver dissection. Other factors include: staff assistance/guidance at first dissection (11\%) and punishment/caution for wrong practices at dissection (3\%).

\section{Discussion}

The results of this study have shown that there was no proper formal course/orientation/lecture on cadaver dissection before it commencement. Perhaps if they were properly oriented earlier of the importance of cadaver dissection to their study, many of the negative attitudes and unacceptable practices reported in this study would have been avoided. It is revealed in this study that most of the students were not assisted at first dissection by staff. The presence of staff should be routine and punctual since it may provide teaching and encouragement to students. These students respect cadaver and also agree that there was no alternative to cadaver dissection. Available literature has shown that cadaver dissection is still considered important and indispensable in anatomy learning [9]

Furthermore most of the respondents were afraid on seeing cadaver for the first time or at subsequent dissection. This explains the sacrosanct value people place on a dead body [10]. The students were jittered or nervous in the laboratory at first sight of cadaver [7]. This has been reported by other literature of strong emotional instability among these students [3] and [11]. This study showed that majority of the students did not collapse but there were very few cases of collapse. Other works reported sympathy of seeing cadaver among student as recorded in this study. This can be linked to love after dead among the living [10].Our study opined that most students agreed that cadaver ghost does not kill, appear in dreams and appear to pursue physically in the laboratory. Again, most students believe that cadaver carries infections. However, the use of protective devices should be intensified. Also, students need to know that these cadavers are properly fixed before use which may protects it from some infections.

Most students did not play/dance, litter dissected parts on the floor, eat / chew, steal dissected parts, involve in unacceptable public Sexual behavior and fight while dissecting. However, most of them agreed that they make noise/gossip and did not cover dissected parts while and after dissection. As revealed in this study, other literature had reported that cadaver dissection enhance understanding of the course [7].

Furthermore, dissection provides true picture of human structure, assist in manual and surgical skills; revealed variations/anomalies of structures and distinguishes medical from non medical students [12] and [9]. We also found in this study that KAP of cadaver dissection can be improved with early formal course/orientations/lecture before dissection, regular staff assistance/guidance at dissections and punishment/caution of students for wrong practices as a deterrent to others.

\section{Conclusion}

This study concludes that there were no formal orientations/lectures offered to most of the students before initial exposure to cadaver dissection. A formal course on KAP of cadaver dissection that will reveal some physical, mental and emotional challenges, benefits of cadaver dissection to their education, avoidable practices and punishment/caution for misconduct should be introduced and made compulsory for all first year preclinical students [4]. Furthermore, we suggest that all staff should be encouraged to be present and assist students at all dissections. However, all students respect cadaver and it importance in their studies as reported in other literature [9]. KAP study of cadaver dissection may differ from center to center and requires further evaluation. 


\section{Acknowledgements}

We wish to thank all the second and third year preclinical students of 2009 to 2010 academic sessions of Universities of Abuja and Maiduguri for spearing time to fill the questionnaires willingly and promptly.

\section{References}

[1] Karlyn E and Rachel W. Knowledge, Attitudes and Practice (KAP) Survey- Summary Report for the Duluth

Lakeside Storm water Reduction Project (LSRP). Saint Paul: Water Resources Center, University of Minnesota. July 2008.

[2] Clayton L T .Taber's Medical Dictionary.18ed. Philadelphia, 1993, 1573.

[3] Evans EJ, Fitzgibbon GH. The Dissecting Room: Reactions of First Year Medical Students. Clinical Anatomy, 5, 1992, 311-320.

[4] Ajita R, Bidyut KD,Gracelee TN, Ibochouba YS. Attitudes and Views of First Year Medical Students Towards Cadaver Dissection in Anatomy Learning Imphal, Manipur, India. Calicut Medical Journal 6(4) 2008 e2

[5] Charlton R,Dovey SM,Jones DG,Blunt A. Effects of Cadaver Dissection on the Attitudes of Medical Students.Med Educ. 1994 Jul; 28(4):290-5.

[6] Gaurav, A and Mandeep, GS.Reactions of First Year Indian Medical Students to the Dissection Hall Experience. NJIRM 1(4), 2010,

[7] Fatemeh J, HashemitabarM, KalantarmahdaviSR, Nahid K. How to Decrease the Emotional Impact of Cadaver Dissection in Medical Students. Pak J Med Sci 22(2), 2006, 200 - 203.

[8] Ellis, H. Teaching in the Dissecting Room. Clin. Anat., 14: 2001, 149-151.

[9] Izunya AM, Oaikhena GA, Nwaopara AO.Attitudes to Cadaver Dissection in a Nigerian Medical School. Asian Journal of Medical Sciences 2(3): 2010, 89-94.

[10] Jones DG. On Ethics, The Human Cadaver: Assessment of the Value we Place on the Dead Body, from a Perspective on Science and Christian Faith. American Scientific Affiliation. 47, 1995. 43-51.

[11] Javadnia F, Hashemitabar M, Kalantarmahdaviand SR, KhajehmougahiN. How to Decrease the Emotional Impact of Cadaver Dissection in Medical Students. Pak. J. Med. Sci. 22(2): 2006, 200-203.

[12] Ziad MB, Tagreed AH, Marwan F, and Abu H. Attitudes and Reactions of Jordan Medical Students to the Dissecting Room. Sur. Radiol.Anat 28:2006, 416-421. 